\title{
PENGALAMAN KELUARGA DALAM MERAWAT PENDERITA SAKIT KRONIS
}

\author{
Annisa Wuri Kartika ${ }^{1,2^{*}}$, Wiwin Wiarsih ${ }^{3}$, Henny Permatasari ${ }^{3}$
}

1. Jurusan Keperawatan, Fakultas Kedokteran, Universitas Brawijaya, Malang 65145, Indonesia

2. Program Studi Magister, Fakultas Ilmu Keperawatan, Universitas Indonesia, Depok 16424, Indonesia

3. Fakultas Ilmu Keperawatan, Universitas Indonesia, Depok 16424, Indonesia

*E-mail: annisa.amariliz@gmail.com

\begin{abstract}
Abstrak
Merawat anggota keluarga yang mengalami sakit kronis memengaruhi kehidupan anggota keluarga secara fisik, psikologis, dan sosial. Tujuan penelitian ini adalah mengetahui pengalaman keluarga dalam merawat anggota keluarga dengan penyakit kronis. Metode penelitian yang digunakan, yaitu kualitatif dengan pendekatan fenomenologi deskriptif. Partisipan merupakan delapan keluarga yang merawat anggota keluarga dengan sakit kronis. Tema yang ditemukan mencakup perubahan status kesehatan penderita, respons psikologis keluarga, upaya untuk mempertahankan kesehatan, dan harapan keluarga. Simpulan penelitian menggambarkan respons yang dialami oleh keluarga berbeda bergantung pada onset, lama, dan prognosis penyakit serta tahapan stres yang dialami keluarga. Perawat dapat memberikan manajemen asuhan keperawatan kepada keluarga berupa intervensi pendidikan kesehatan mengenai penyakit kronis, psikoedukasi, dan konseling keluarga dalam merawat penderita sakit kronis.
\end{abstract}

Kata kunci: merawat, pengalaman keluarga, penyakit kronis

\begin{abstract}
The Experience of Family Caregivers of Persons with Chronic Illness. Caring for family member with chronic illness affects the lives of family physically, psychologically, and socially. The aim of this study was to describe the experience of family member in caring for family members with chronic illness. A qualitative design with descriptive phenomenological approach was chosen for this study. Qualitative interviews with eight families were performed. The results included a changed health status for the person with chronic illness, family psychological response, efforts of maintain health and family expectations about type and quality of health services. Conclusion of research illustrated that response experienced by families were different depending on the onset, duration, and prognosis of the diseases and the stage of stress experienced by the family. Thus nurses could provide nursing care to family with chronic illness which are consist of health education and counseling in order to caring for family members with chronic illness.
\end{abstract}

Keywords: caregiver, chronic disease, family experience

\section{Pendahuluan}

Penyakit kronis merupakan salah satu beban ganda dalam bidang kesehatan selain penyakit infeksi yang merajalela. Diprediksikan pada tahun 2020 penyakit tidak menular akan mencapai $73 \%$ dari penyebab kematian dan $60 \%$ dari beban penyakit dunia (World Health Organization, 2002). Data kesehatan di Indonesia, khususnya Kota Depok menunjukkan kasus kematian akibat stroke empat tahun berturut-turut menempati urutan pertama. Penyebab utama stroke pada umumnya adalah hipertensi, diabetes mellitus (DM) yang tidak terkontrol, serta penyakit jantung. Hal ini saling berkaitan dengan urutan tertinggi penyebab kematian di Kota Depok (Dinas Kesehatan Depok, 2007).

Penyakit kronis tidak hanya mengakibatkan kesakitan, kematian, dan ketidakmampuan fisik dari penderita, namun juga prosedur pengobatan yang panjang dan menghabiskan banyak biaya 
(Denham \& Looman, 2010). Oleh karena itu, sistem pelayanan kesehatan pada klien kronis berubah dengan memperpendek masa rawat inap di Rumah Sakit dan beralih pada program perawatan di rumah (home-based care) yang memberikan keuntungan secara materi karena dapat menekan biaya perawatan (Lim \& Zebrack, 2004). Penelitian yang dilakukan Moalosi, Phatswane, Moeti, Binkin dan Kenyon (2003) melaporkan bahwa penurunan biaya sebesar $44 \%$ pada klien yang dirawat di rumah dibandingkan dengan biaya perawatan di rumah sakit. Selain efektif dalam hal biaya, program perawatan di rumah juga efektif dalam hal proses pengobatan. Hasil penelitian Gomes, Boas, dan Foss (2012) menyebutkan bahwa dukungan sosial yang diberikan oleh keluarga klien DM secara langsung berhubungan dengan kepatuhan pengobatan, klien yang mendapatkan dukungan sosial baik memiliki perilaku kontrol glikemi yang tinggi, sedangkan klien yang mendapatkan dukungan sosial kurang memiliki perilaku kontrol glikemi rendah.

Peran dan fungsi keluarga dalam teori sistem salah satunya adalah sebagai pemberi perawatan (caregiver) pada anggota keluarga yang sakit. (Smith, Greenberg, \& Seltzer, 2007). Lim dan Zebrack (2004) menyatakan bahwa konsep normalisasi pada keluarga yang memiliki anggota keluarga dengan penyakit kronis dilakukan dengan merubah gaya hidup yang mendukung proses pengobatan. Kegiatan-kegiatan tersebut antara lain melakukanpemeriksaan rutin, manajemen perawatan diri, perubahan pola makan, aktivitas fisik, dan memaksimalkan dukungan emosional dilakukan untuk memberikan kenyamanan (Lim \& Zebrack, 2004). Studi yang dilakukan Knafl dan Gilliss (2002) menyebutkan bahwa meskipun konsep normalisasi keluarga merupakan proses adaptif, namun beberapa keluarga mengalami kesulitan dalam menjalani rutinitas yang stabil berhubungan dengan proses pengobatan yang lama, perubahan aktivitas fisik, serta perubahan peran dan tanggung jawab. Tingkat kemandirian anggota keluarga yang mengalami sakit kronis juga mempengaruhi tantangan yang dihadapi keluarga, keluarga dengan anak SHCN (Special Health Care Needs) melaporkan bahwa mereka tidak hanya mengalami stress emosional tapi juga beban finansial (Denham \& Looman, 2010). Di Amerika Serikat, 40\% keluarga melaporkan mengalami beban finansial ketika merawat anak mereka dengan SHCN (Looman, O'Conner-Von, Ferski, \& Hildenbrand, 2009).

Keperawatan keluarga merupakan tingkat pelayanan kesehatan masyarakat yang dipusatkan pada keluarga sebagai unit kesatuan dengan tujuan pelayanan dan perawatan sebagai upaya pencegahan penyakit (Friedman, Bowden, \& Jones, 2010). Keluarga yang mendapatkan dukungan dari lingkungan sosialnya mengalami tingkat stres yang lebih rendah daripada yang tidak mendapatkan dukungan sosial. Hal ini menggambarkan bahwa pentingnya peran perawat sebagai konselor untuk mengarahkan keluarga dalam menggunakan strategi koping yang positif (Allender, Rector, \& Warner, 2010). Oleh karena itu, tujuan penelitian ini adalah untuk menggali pengalaman keluarga dalam merawat klien dengan penyakit kronis di rumah.

\section{Metode}

Metode penelitian yang digunakan adalah kualitatif dengan pendekatan fenomenologi deskriptif. Partisipan yang terlibat merupakan keluarga yang merawat anggota keluarga dengan sakit kronis. Pemilihan partisipan dilakukan dengan menggunakan teknik purposive sampling dengan kriteria inklusi: (1) keluarga adalah keluarga inti (anggota keluarga terdiri atas orang tua dan anak yang tinggal dalam satu rumah) yang merawat anggota keluarga yang mengalami penyakit kronis minimal dalam jangka tiga bulan. Hal ini didasarkan pada penelitian Vedhara, Shanks, Anderson, dan Lightman (2000) yang menyatakan stress pada caregiver terjadi pada rentang waktu bulan ke-3 dan ke-6 dan tinggal serumah dengan penderita sakit kronis, (2) bersedia ikut sebagai partisipan, (3) mampu menceritakan pengalamannya dengan baik, (4) berusia di atas delapan belas tahun, sesuai dengan data dari The National Alliance for Caregiving and AARP (2009) yang menyatakan bahwa rentang usia rata-rata caregiver adalah 1849 tahun. Saturasi data pada penelitian ini dicapai pada partisipan ke-8. 
Pengumpulan data dilakukan dengan wawancara mendalam, menggunakan voice recorder dan catatan lapangan. Teknik wawancara dilakukan dengan semi structured interview dan jointinterview yang melibatkan dua orang dalam satu unit keluarga. Metode analisis data yang digunakan adalah metode Colaizzi yang melibatkan partisipan penelitian untuk memvalidasi hasil penelitian (Burns \& Grove, 2009).

Salah satu komponen inti yang menentukan kualitas output dari keseluruhan proses penelitian kualitatif adalah keabsahan data (trustworthiness). Dalam Speziale (2003) dinyatakan bahwa untuk dapat menjamin keabsahan data maka peneliti menerapkan empat kriteria keabsahan data, yaitu credibility, dependability, confirmability, dan transferability. Hal tersebut dilakukan dengan strategi pengecekan kembali oleh partisipan. Data berupa analisis tematik yang telah dihimpun oleh peneliti ditunjukkan kepada partisipan untuk dibaca ulang dan dilakukan verifikasi terhadap keakuratan data. Prinsip transferability dilakukan dengan membandingkan hasil penelitian yang telah dilakukan dengan keluarga yang merawat penderita penyakit kronis di Kelurahan CP yang belum menjadi partisipan karena tidak mendapatkan kesempatan untuk ikut serta dalam penelitian setelah tercapai saturasi data. Prinsip confirmability dilakukan dengan melibatkan auditor eksternal, yaitu pembimbing dan penguji mulai dari proses pembuatan proposal, pengumpulan data, analisa dan interpretasi data serta rekomendasi penelitian (Pollit \& Beck, 2010).

\section{Hasil}

Tema yang ditemukan mencakup respons psikologis keluarga, upaya untuk mempertahankan kesehatan, dan harapan keluarga dengan jenis dan kualitas layanan baik.

Respons Psikologis Keluarga. Tema ini dibentuk dari subtema perasaan takut, bingung, sedih, khawatir, dan menerima. Perasaan kaget, takut, sedih, dan khawatir yang dialami oleh partisipan merupakan respons awal ketika anggota keluarga mulai menunjukkan gejala sakit. Perasaan tersebut diwakili dalam pernyataan sebagai berikut.
"Yang pertama dulu.... tiba-tiba aja waktu itu tidur..saya, kan, tidur di sebelahnya..tiba-tiba kejang gitu ya.... Ya kaget ya... bingung, langsung panggil adeknya" (Partisipan 8a).

"Yang namanya takut mah..kira-kira...yang namanya kata orang ya penyakit itu agak sedikit...agak sedikit gawat juga, takutnya ya kayak gitu” (Partisipan 6a).

"Kalau B lagi kambuh, trus juga kalau ngomongin B juga enggak kuat beneeer (menangis dan mengelus dada)..ini hati waswas aja kak, gitu ceritanya" (partisipan 3a).

Respons lain yang muncul adalah perasaan menerima yang diwujudkan dalam pernyataan biasa saja karena penyakit tersebut sudah berlangsung lama dan karena sakit merupakan musibah dan cobaan dari Tuhan. Hal tersebut diwakili dalam pernyataan berikut.

"Udah biasa, sih, sekarang karena udah lama" (partisipan 7b).

"Enggak...merupakan biasa saja, tapi anggap kita itu adalah musibah, cobaan Tuhan buat apa...buat hidup kita itu di situ" (partisipan la).

Upaya Mempertahankan Kesehatan. Hasil analisis tema menyatakan bahwa upaya mempertahankan kesehatan yang dilakukan keluarga dalam mengatasi penyakit yang menimpa anggota keluarga mereka dibentuk dari tiga subtema, yaitu membawa ke fasilitas layanan kesehatan, melakukan tindakan perawatan di rumah, serta melakukan upaya pengobatan tradisional dan alternatif.

Semua partisipan menyatakan bahwa yang pertama kali mereka lakukan ketika anggota keluarga mereka menunjukkan gejala sakit adalah membawa ke layanan kesehatan, yaitu tempat praktik dokter, rumah sakit, atau puskesmas. Hal ini diwakili oleh pernyataan berikut.

“...sering batuk, trus seseknya...tadinya ke puskesmas, trus uwaknya ngajakin, tuh, waktu kelas empat ke spesialis" (Partisipan 3a). 
Keluarga mengungkapkan bahwa mereka melakukan tindakan perawatan untuk mengatasi penyakit yang diderita oleh anggota keluarga selama dirawat di rumah. Beberapa tindakan perawatan yang dilakukan terangkum dalam kategori merawat luka pada klien DM, mengatur perilaku, dan pengaturan pola makan sebagai upaya pencegahan penularan penyakit, dan monitor kesehatan anggota keluarga yang sakit. Salah satu partisipan menyatakan bahwa:

"Di rumah saya praktekkan itu...merawat korengkoreng yang bekas dikorek sama dokter bedah...saran-sarannya, trus suntikannya" (Partisipan 1a).

"Bahkan rokoknya Bapak sekarang saya ambil... jadi udah berkurang sekarang" (Partisipan, 8a).

"Dikasih pola makan...pantangan dikasih tahu semua" (Partisipan, 6a).

Upaya pengobatan lainnya adalah melakukan pengobatan alternatif. Hal tersebut diwakili dalam pernyataan berikut.

"Sepupu saya gini...eh, coba Mbak sebelum di CT-scan ke ini aja, ke alternative (...) ditotok gitu lo, Mbak" (Partisipan 2a).

Pemanfaatan obat tradisional dinyatakan oleh partisipan untuk menggambarkan jenis obat yang digunakan. Jenis obat tradisional yang digunakan adalah herbal atau tumbuh-tumbuhan yang memiliki khasiat untuk menyembuhkan penyakit tertentu. Salah satu partisipan mengungkapkan.

"Daun itu sirsak, itu yang kita pake rutin, akar alang-alang tapi enggak lama" (Partisipan $8 a)$.

Harapan Keluarga: Jenis dan Kualitas Layanan Baik. Tema jenis dan kualitas layanan baik dibentuk dari subtema pernyataan mengenai keinginan keluarga tentang jenis layanan yang tepat untuk penderita sakit kronis dan kualitas layanan oleh tenaga kesehatan.
Partisipan menyatakan kebutuhan terhadap adanya informasi mengenai cara perawatan yang tepat serta layanan home care yang mereka anggap tepat karena membawa manfaat dan efektif. Hal ini seperti yang dinyatakan oleh partisipan berikut.

"Kalau saya, sih, lebih pasnya ada pelayanan ke rumah" (Partisipan 7a).

Subtema kualitas layanan oleh tenaga kesehatan dibentuk dari kategori harapan agar perawat dapat bekerja dengan profesional. Pernyataan-pernyataan tersebut diungkapkan oleh salah satu partisipan sebagai berikut.

"Lebih bisa menjalani profesi sebagai perawat, memahami klien ya, dengan baik,.., tidak membeda-bedakan klien bagi dari kelas sosial maupun apa ya...klien itu bisa termotivasi untuk sembuh ya Mbak, dari pelayanan keperawatannya gitu" (Partisipan 6b).

\section{Pembahasan}

Pengalaman merawat anggota keluarga dengan penyakit kronis menghasilkan tema yang menggambarkan dinamika keluarga setelah anggota keluarga menderita sakit kronis. Hal tersebut meliputi respons keluarga, upaya keluarga mempertahankan kesehatan keluarga, dan layanan kesehatan yang diharapkan.

Keluarga yang hidup dengan penderita sakit kronis menghadapi tantangan berat dalam hidup mereka berupa stress, kecemasan dan kemarahan akibat rutinitas pengobatan yang harus mereka lakukan (Denham \& Looman, 2010). Stressor tersebut memicu munculnya respon stres yang dapat dijelaskan dengan respon kehilangan oleh Kubler-Ross (1969) (Kozier, Erb, Berman, \& Snyder, 2004). Hasil penelitian menggambarkan respons keluarga bergantung pada onset, lama, dan prognosis penyakit serta tahapan stres yang dialami oleh keluarga. Respons pertama yang diungkapkan keluarga adalah adalah penyangkalan atau shock dan tidak percaya yang ditunjukkan dengan perasaan bersalah dan sedih, tidak percaya, dan penolakan terhadap kehilangan. Reaksi 
pertama tersebut dipengaruhi oleh persepsi keluarga terhadap keparahan penyakit yang diderita klien. Respons tersebut kemudian diikuti dengan perasaan marah, tawar-menawar, kesedihan yang mendalam serta diakhiri dengan penerimaan.

Hasil penelitian ini menggambarkan bahwa tahap pertama dari berduka yang dialami keluarga adalah munculnya respons kaget dan takut. Mayoritas partisipan yang menyatakan kekagetannya disebabkan oleh perubahan fisik atau gejala yang dialami oleh anggota keluarga mereka yang muncul tiba-tiba dan tidak ada keluhan sebelumnya. Selain kaget, keluarga juga merasakan takut karena mengetahui bahwa penyakit tersebut dapat berakibat buruk terhadap keselamatan istrinya. Seperti hasil penelitian pada klien $\mathrm{Ca}$. Mammae yang menyatakan bahwa respon emosional yang ditampilkan oleh pasangan ketika masa diagnosis, pengobatan dan perjalanan penyakit meliputi perasaan kaget, tidak percaya, penyangkalan, marah, rasa bersalah, depresi, kecemasan, ketidakyakinan akan prognosis penyakit, ketakutan, kehilangan kontrol dan persepsi lain yang menyertai (Hilton, Crawford, \& Tarko, 2000).

Respons psikologis lain adalah perasaan menerima sebagai hasil dari respons adaptasi. Perasaan menerima ini diungkapkan keluarga saat penyakit tersebut sudah berlangsung lama dan mereka sudah terbiasa dengan kondisi klien. Selain itu keluarga juga merasa bahwa sakit yang dialami anggota keluarga mereka merupakan cobaan dari Tuhan yang harus mereka jalani. Penerimaan yang muncul merupakan respons dari respon reorganisasi perasaan berduka terhadap individu yang telah menerima kenyataan yang terjadi serta mendapatkan gambaran tentang penyebab masalah dan secara bertahap menyesuaikan diri dengan keadaan yang dialami. Keluarga tersebut menyatakan bahwa ketika menghadapi stressor pertama kali, mereka berusaha untuk menyelesaikan masalah sakit dengan melakukan tindakan pengobatan. Namun, ketika stressor sudah berlangsung lama dan keluarga mereka tidak kunjung sembuh, keluarga kemudian percaya bahwa sakit yang dialami keluarga merupakan bentuk cobaan dari Tuhan untuk keluarga mereka.
Hal ini menggambarkan bahwa dalam tahap penerimaan juga terdapat respons kepasrahan terhadap takdir yang merupakan bagian dari mekanisme turning to religion.

Persepsi dan respons emosional yang menyertai keluarga bergantung pada koping yang dimiliki keluarga. Tahap pertama dimulai dengan menggunakan strategi problem-focused. Hal ini dilakukan dengan mencari dan belajar lebih banyak mengenai penyakit dan proses pengobatan yang harus dilakukan. Strategi selanjutnya adalah emotional-focused yang ditunjukkan dengan penerimaan dan kepasrahan, digunakan ketika mereka merasa bahwa sudah tidak ada lagi yang bisa mereka lakukan untuk mengubah situasi yang membahayakan atau mengancam (Lovelace, 2012; Demirtepe, 2008). Salah satunya adalah dengan turning to religion. yaitu situasi ketika individu merasa putus asa dengan keadaan yang tidak segera membaik (Demirtepe, 2008).

Upaya pengobatan dipengaruhi oleh informasi yang didapatkan mengenai penyakit dan persepsi masyarakat mengenai kemanfaatan dan sumber daya yang dimiliki. Mayoritas partisipan menyatakan bahwa mereka meminta bantuan tenaga kesehatan ketika pertama kali keluarganya mengalami sakit. Upaya yang kedua adalah menggunakan pengobatan alternatif dan obatobat tradisional untuk menyembuhkan penyakit. Alasan yang diungkapkan keluarga antara lain adalah biaya pengobatan di tenaga kesehatan yang mahal, sedangkan di pengobatan alternatif dan penggunaan obat tradisional menghabiskan biaya lebih murah dan lebih terasa efeknya.

Penderita sakit kronis pada umumnya menggunakan fasilitas layanan kesehatan tradisional dan alternatif karena adanya pengalaman positif yang didapatkan dari pengobatan alternatif tersebut (Chen, Huang, Lin, Smith, \& Liu, 2009). Kemudahan akses dan kenyamanan yang dirasakan juga menjadi alasan bagi masyarakat memilih penyembuh tradisional, serta rekomendasi dari orang lain tentang keberhasilan dan manfaat yang diperoleh (Chao, Wade, \& Kronerberg, 2006; Chen, et al., 2009). Prinsip ekonomi juga memengaruhi pilihan pemanfaatan akses 
layanan kesehatan, meskipun pengobatan medis memberikan kemajuan terhadap kondisi kesehatan klien, keluarga akan tetap memilih pengobatan alternatif karena biaya yang lebih murah dan terjangkau. Faktor ketakutan penderita terhadap proses pengobatan juga mendorong penderita dan keluarga memilih pengobatan alternatif dengan harapan dapat memberikan kesembuhan tanpa harus menjalani operasi.

Upaya lain yang dilakukan keluarga adalah upaya perawatan di rumah. Penelitian Knafl dan Gilliss (2002) menggambarkan proses adaptasi keluarga yang hidup dengan penderita penyakit kronis antara lain adalah konsep normalisasi dengan meletakkan rutinitas perawatan penyakit dalam aktivitas keseharian mereka termasuk perubahan gaya hidup sesuai dengan rencana pengobatan yang dijalani penderita. Proses adaptasi yang ditunjukkan keluarga termasuk juga melakukan kegiatan yang mereka percaya secara rasional dapat mengurangi dampak penyakit atau bahkan menyembuhkan. Alasan rasional ini bisa saja muncul akibat pengalaman terdahulu bahwa kegiatan tersebut berhasil mengatasi masalah seperti yang disebutkan partisipan yang menyatakan bahwa dengan memberikan air hangat maka dapat mencegah batuk dan sesak napas yang diderita anak sehingga dapat disimpulkan bahwa kegiatan perawatan yang dilakukan keluarga dalam penelitian ini menggambarkan bahwa mereka melakukan upaya mempertahankan kesehatan berdasarkan informasi yang pernah diterima maupun alasan yang dipercaya keluarga dapat menyembuhkan penyakit.

Perawat dapat menerapkan strategi "Empat R" untuk memahami konsep normalisasi tersebut, yaitu dengan remediation, redefinition, realignment dan re-education. Remediation adalah tahapan ketika keluarga menempatkan rutinitas pengobatan dalam kehidupan keluarga seharihari. Redefinition merupakan strategi terhadap seluruh anggota keluarga terlibat secara emosional dalam memahami perubahan rutinitas yang telah ditetapkan. Hal ini membuat keluarga menyesuaikan diri dengan kerelaan, bukan paksaan. Realignment terjadi bila dalam prosesnya, terjadi ketidaksetujuan dalam anggota keluarga mengenai rutinitas medis yang dilakukan. Proses selanjutnya adalah re-education, indikasinya adalah terdapat dis-organisasi atau ketidak teraturan pada keluarga dalam proses menjalani rutinitas pengobatan (Fiese \& Everhart, 2006).

Karakteristik penyakit kronis yang berlangsung dalam jangka waktu lama membawa dampak terhadap proses pengobatan yang dilaksanakan berkali-kali. Letak fasilitas layanan kesehatan yang memadai untuk mengobati penyakit kronis kadang menyulitkan keluarga untuk mengakses fasilitas layanan kesehatan. Hambatan transportasi karena tidak memiliki kendaraan sendiri memunculkan masalah membengkaknya biaya untuk transportasi. Kesulitan tersebut membuat keluarga menilai bahwa kunjungan rumah oleh tenaga kesehatan merupakan bentuk layanan yang tepat diberikan kepada klien dengan penyakit kronis. Hal ini digambarkan dalam pernyataan keluarga bahwa layanan home visit yang dilakukan tenaga kesehatan sangat membantu dan dinilai tepat bagi penderita kronis dan keluarga.

Penanganan terbaik untuk mengatasi penyakit kronis adalah dengan mencegah terjadinya penyakit kronis melalui manajemen dan modifikasi perilaku kesehatan (Glasgow, Orleans, \& Wagner, 2001). Proses modifikasi perilaku kesehatan tersebut dapat dilakukan dengan optimal jika tenaga kesehatan dapat meningkatkan peran serta keluarga untuk mendukung upaya peningkatan kesehatan penderita sakit kronis. Eksplorasi pengalaman keluarga dalam membangun koping dan mekanisme adaptasi penting bagi perawat agar mampu memberikan edukasi yang sesuai dengan kebutuhan dan kondisi klien.

\section{Kesimpulan}

Respons keluarga ketika salah satu anggota keluarga menderita sakit kronis terdiri atas respons psikologis dan upaya mempertahankan kesehatan. Respons psikologis yang ditampilkan bergantung pada onset penyakit, lama, dan tingkat keparahan penyakit. Di sisi lain, upaya pengobatan yang dilakukan oleh keluarga dipengaruhi oleh informasi mengenai penyakit dan persepsi masyarakat mengenai kemafaatan dan sumber daya 
yang dimiliki. Layanan kesehatan tidak lagi menjadi pilihan utama karena kendala biaya kesehatan yang tinggi dan masyarakat lebih percaya terhadap manfaat yang diperoleh dari obat tradisional dan penyembuhan komplementer. Pengalaman keluarga juga menjadi salah satu faktor penting bagi keluarga dalam menerapkan strategi perawatan yang efektif terhadap anggota keluarga yang mengalami sakit kronis.

Perawat dapat mengembangkan strategi yang tepat dalam bentuk kunjungan rumah bagi keluarga dengan penderita sakit kronis. Manajemen asuhan keperawatan kepada keluarga dilakukan dengan mengkaji respons adaptasi keluarga. Perawat perlu melakukan pengkajian yang mendalam mengenai persepsi keluarga mengenai penyakit kronis terutama pengetahuan mengenai proses perjalanan penyakit. Rencana intervensi berupa psikoedukasi mengenai koping dan pendidikan kesehatan mengenai cara perawatan diberikan pada fase awal keluarga mengetahui sakit yang diderita anggota keluarganya. Pendidikan kesehatan mengenai jenis terapi tradisional yang manfaatnya telah terbukti secara ilmiah perlu diberikan untuk mendukung upaya perawatan yang dilakukan keluarga di rumah (MR, JS, PN).

\section{Referensi}

Allender, J.A., Rector, C., \& Warner, K.D. (2010). Community health nursing: Promoting and protecting the public's health (7th Ed.). Philadelphia: Lippincott Williams \& Wilkins.

The National Alliance for Caregiving and AARP. (2009). Selected caregiver statistic. Family Caregiver Alliance. Diperoleh dari http://www.caregiver.org/caregiver/jsp/con tent_node.jsp?nodeid=439

Burns, N., \& Grove, S.K. (2009). The Practice of nursing research: Appraisal, synthesis, and generation of evidence. St. Louis Missouri: Saunders Elsevier.

Chao, M.T., Wade, C., \& Kronerberg. (2006). Womens reason for complementary and alternative medicine use: Rasial ethnc difference. Journal of Altern Complemen Medicine. 12 (8), 719-720.
Chen, LL., Huang, LC.,Lin, SC., Smith, M., Liu, SJ., (2009). Use of folk remedies among families of children hospitalize in Taiwan. Journal of Clinical Nursing. 18, 2162-2179.

Demirtepe, D. (2008). Testing the caregiver stress model with the caregivers of children with leukemia (Thesis, Middle East Technical University). Middle East Technical University.

Denham, S.A., \& Looman, W. (2010). Families With Chronic Illness, dalam Kaakinen, et al, Family Health Care Nursing, Theory, Practice and Research (4th Ed.). F.A Davis Company: Philadelphia. Hal 235272.

Dinas Kesehatan Depok (2007). Profil dinas kesehatan depok Tahun 2007. Depok: Dinkes Depok.

Fiese, B.H., \& Everhart, R.S. (2006). Medical adherence and childhood chronic illness: Family daily management skills and emotional climate as emerging contributors. Current Opinion in Pediatrics, 18 (5), 551-557.

Friedman, Bowden, \& Jones. (2010). Family nursing: Research, theory, and parctice. New Jersey: Prentice Hall.

Gomes, C., Boas, V., \& Foss, M. (2012). Relationship among social support, treatment adherence and metabolic control of DM patient. Rev-Latno Am, 20 (1), 52-58.

Glasgow, R.E., Orleans, C.T., \& Wagner, E.H. (2001). Does the Chronic Care Model serve also as a template for improving prevention? The Milbank Quarterly, 79(4), 579-612.

Hilton, B.A., Crawford, J.A., \& Tarko, M.A. (2000). Men's Perspectives on Individual and Family Coping with Their Wive's Breast Cancer and Chemotherapy. West Journal Nurse Res, 22, 438.

Knafl, K.A., \& Gilliss, C. (2002). Families and chronicc illness: A synthesis of current research. Journal of Family Nursing, 8 (3), 178-198. 
Kozier, B.J., Erb, G., Berman, A., \& Snyder, S. (2004). Fundamental of nursing: Concept, process, and practice (7th Ed.). Upper Saddle River: Perason Education Inc.

Lim, J., \& Zebrack, B. (2004). Caring family members with chronic physical illness: A critical review of caregiver literature. Health and Quality of Lifes Outcomes, 2, 50. doi: 10.1186/1477-7525-2-50.

Looman, W. S., O'Conner-Von, S. K., Ferski, G. J., \& Hildenbrand, D.A. (2009). Financial and employment problems in families of children with special health care needs: Implications for research and practice. Journal of Pediatric Health Care, 23 (2), $117-125$.

Lovelace, L.M. (2012). The Effect of coping strategies on burden among male alzheimers caregivers (Thesis, Lousiana State University). B.S. Lousiana State University.

Moalosi, G.F., Phatswane, J., Moeti, T., Binkin, N., \& Kenyon. T. (2003). Cost-effectiveness of home based care versus hospital care for chronically ill tuberculoasis Patients, Francistown, Botswana. International Journal Tuberculosis Lung Disease, 7, 8085.
Pollit, D.F., \& Beck, C.T. (2010). Essential of nursing research: appraising evidence for nursing practice. Philadelphia: Lippincot Williams \& Wilkins.

Smith, M., Greenberg, J., \& Seltzer, M. (2007). Siblings of adults with schizophrenia: Expectations about future care giving roles. American Journal of Orthopsychiatry. 77, 29-37.

Speziale, H.J.S. (2003). Designing data generation and management strategies. In Speziale, H.J.S., \& Carpenter, D.R. (Ed.) Qualitative research in nursing: Advancing the humanistic imperative. Philadelphia: Lippincott Williams \& Wilkins.

Vedhara, K., Shanks, N., Anderson, S., \& Lightman, S. (2000). The role of stressors and psychosocial variables in the stress process: A study of chronic caregiver stress. Psychosomatic Medicine, 62, 374385 .

WHO. (2002). Integrated chronic disease prevention control. Diperoleh dari http://www.who.int/chp/about/integrated $\mathrm{cd} / \mathrm{en} / \mathrm{index} \cdot \mathrm{html}$. 